\title{
Pembelajaran Bahasa Arab Dengan Pemanfaatan Teknologi
}

\author{
Rahmat Iswanto \\ Sekolah Tinggi Agama Islam Negeri (STAIN) Curup \\ rahmatiswanto.database@gmail.com
}

\begin{abstract}
Abstrak
Tulisan ini mengkaji tentang bagaimana teknologi dapat dimanfaatkan dalam proses pembelajaran bahasa Arab. Berbagai permasalahan pembelajaran bahasa Arab sesuai dengan konteks yang dihadapi di berbagai lembaga pendidikan, tenaga pengajar memungkinkan melakukan modifikasi metode belajar mengajar. Hal ini dapat dilakukan dengan perkembangan teknologi yang memuat banyak informasi yang dapat digunakan untuk peningkatan hasil belajar. Pembahasan tentang penerapan teknologi dalam pembelajaran bahasa Arab memuat pertanyaan yaitu bentuk teknologi yang seperti apa yang dapat dimanfaatkan, apakah teknologi dapat berperan dalam keselarasan dan keberlanjutan pembelajaran bahasa Arab dari tingkat dasar hingga tingkat menengah atas, apakah teknologi dapat membuat peserta didik akan semakin tertarik mempelajari bahasa Arab, apakah teknologi dapat menciptakan realisasi dan relevansi dengan apa yang dirasakan peserta didik, apakah teknologi dapat menciptakan media-media pembelajaran bahasa Arab yang lebih bervariasi yang selama ini masih terasa kurang, apakah teknologi dapat meningkatkan kemampuan atau kompetensi guru dalam mengajar bahasa Arab, apakah teknologi mampu memanfaatkan alokasi waktu untuk pembelajaran bahasa Arab, apakah teknologi mampu menciptakan lingkungan berbahasa Arab. Melalui metode diskriptif kualitatif, tulisan ini menyimpulkan beberapa pertanyaan di atas.
\end{abstract}

Kata kunci: Bahasa Arab, Pembelajaran, Teknologi Pembelajaran

\begin{abstract}
This article examines how technology can be utilized in the process of Arabiclearning. Many problems of learning of Arabic language in accordance with the context faced in various educational institutions, a teacher allows modification formethodsof teaching and learning. This can be done with technological developments that contain lots of information that can be used to improve learning
\end{abstract}

Arabiyatuna : Jurnal Bahasa Arab, Vol. 1, No. 2, 2017

STAIN Curup | ISSN 2580-5053 (e), 2580-5045 (p)

Available online: http://journal.staincurup.ac.id/index.php/arabiyatuna 
outcomes. Discussion about the application of technology in learning Arabic contains the question of what kind of technology that can be utilized, whether the technology can play a role in the alignment and sustainability of learning Arabic from basic to middle level, whether the technology can make learners will be more interested in learning the Arabiclanguage, whether the technology can create realization and relevance to what the students perceived, whether the technology can create Arabic learning media more varied that still lacks, whether the technology can improve the ability or competence of teachers in teaching Arabic, whether technology is able to take advantage of time allocation for learning Arabic, whether the technology is able to create an Arabic speaking environment. Through qualitative descriptive method, this article summarizes some of the above questions.

Key words: Arabic Language, Learning, Learning Technology

\section{Pendahuluan}

Bahasa adalah alat untuk menumpahkan isi hati, pikiran seseorang terhadap lawan bicaranya. Berbahasa merupakan media terpenting bagi manusia untuk melakukan interaksi dengan orang lain. Terkait dengan bagaimana orang menilai belajar bahasa Arab, banyak sudut pandang yang heterogen. Sebagian ada yang memandang bahasa Arab adalah bahasa agama, karena bahasa arab dipandang sebagai alat untuk mempelajari teks-teks suci yang berbahasa Arab. Ada yang berpandangan belajar bahasa Arab adalah belajar bahasa ilmu pengetahuan islam. pandangan ini juga tidak salah, karena memang ilmu-ilmu islam mayoritas referensinya berbahasa Arab. Dan ada pula yang berpandangan bahwa belajar bahasa arab adalah belajar berbahasa. Pandangan ini lebih menitik beratkan pada bagaimana orang belajar bahasa Arab sebagai bahasa komunikasi sehari-hari.

Perbedaan sudut pandang ini, menyebabkan adanya perbedaan metode, teknik, bahan ajar, media pembelajarannya. Jika, bahasa Arab sebagai alat komunikasi, maka belajar bahasa Arab lebih menitik beratkan pada bagaimana anak didik banyak praktik dan terampil untuk berbicara dengan menggunakan bahasa Arab, baik menyimak, berbicara, membaca, maupun menulisnya. Terlepas dari berbagai sudut pandang tersebut, jika kita amati dengan seksama, maka pembelajaran bahasa arab banyak menemui berbagai kendala dan hambatan.

Teknologi diartikan sebagai keseluruhan sarana untuk menyediakan barang-barang yang diperlukan bagi kelangsungan dan kenyamanan 
hidup manusia ${ }^{1}$.Istilah teknologi pendidikan sering dihubungkan dengan teori belajar dan pembelajaran. Bila teori belajar dan pembelajaran mencakup proses dan sistem dalam belajar dan pembelajaran, teknologi pendidikan mencakup sistem lain yang digunakan dalam proses mengembangkan kemampuan manusia.

Membahas tentang penerapan teknologi dalam pembelajan bahasa Arab yang dimaksudkan adalah bagaimana teknologi dapat menjawab permasalahan permasalahan yang ada dalam pembelajaran bahasa Arab.Apakah teknologi dapat berperan dalam keselarasan dan keberlanjutan pembelajaran bahasa Arab dari tingkat dasar hingga tingkat menengah atas? Apakah dengan teknologi dapat membuat peserta didik akan semakin tertarik mempelajari bahasa Arab? Apakah dengan teknologi dapat menciptakan realisasi dan relevansi dengan apa yang dirasakan peserta didik? Apakah dengan teknologi dapat menciptakan mediamedia pembelajaran bahasa Arab yang lebih bervariasi yang selama ini masih terasa kurang?Apakah teknologi dapat meningkatkan kemampuan atau kompetensi guru dalam mengajar bahasa Arab?Apakah dengan teknologi mampu memanfaatkan alokasi waktu untuk pembelajaran bahasa Arab?Apakah melalui teknologi mampu menciptakan lingkungan berbahasa Arab?

\section{Pembelajaran Bahasa Arab}

Bahasa Arab (al-lughah al-'Arabiyyah, atau secara ringkas 'Arabi) adalah salah satu bahasa Semit Tengah, yang termasuk dalam rumpun bahasa Semit dan berkerabat dengan bahasa Ibrani dan bahasa-bahasa Neo Arami. Bahasa Arab memiliki lebih banyak penutur daripada bahasa-bahasa lainnya dalam rumpun bahasa Semit. Ia dituturkan oleh lebih dari 280 juta orang ${ }^{[1]}$ sebagai bahasa pertama, yang mana sebagian besar tinggal di Timur Tengah dan Afrika Utara. Bahasa ini adalah bahasa resmi dari 25 negara, dan merupakan bahasa peribadatan dalam agama Islam karena merupakan bahasa yang dipakai oleh AlQur'an. Berdasarkan penyebaran geografisnya, bahasa Arab percakapan memiliki banyak variasi (dialek), beberapa dialeknya bahkan tidak dapat saling mengerti satu sama lain. Bahasa Arab modern telah diklasifikasikan sebagai satu makrobahasa dengan 27 sub-bahasa dalam ISO 639-3.Bahasa Arab Baku (kadang-kadang disebut Bahasa Arab Sastra) diajarkan secara luas di sekolah dan universitas, serta digunakan di tempat kerja, pemerintahan, dan media massa.

Bahasa Arab Baku berasal dari Bahasa Arab Klasik, satu-satunya anggota rumpun bahasa Arab Utara Kuna yang saat ini masih digunakan, sebagaimana terlihat dalam inskripsi peninggalan Arab pra-Islam yang berasal dari abad ke-4. ${ }^{2}$

1Lihat https:/ /id.wikipedia.org/wiki/Teknologi, diakses 16 Nopember 2017

${ }^{2}$ Versteegh, Kees (1997), The Arabic Language, hlm. 33. Edinburgh University Press, ISBN 90-04-17702-7 
Bahasa Arab Klasik juga telah menjadi bahasa kesusasteraan dan bahasa peribadatan Islam sejak lebih kurang abad ke-6.Abjad Arab ditulis dari kanan ke kiri.

Bahasa Arab telah memberi banyak kosakata kepada bahasa lain dari dunia Islam, sama seperti peranan Latin kepada kebanyakan bahasa Eropa. Semasa Abad Pertengahan bahasa Arab juga merupakan alat utama budaya, terutama dalam sains, matematika dan filsafah, yang menyebabkan banyak bahasa Eropa turut meminjam banyak kosakata dari bahasa Arab.

Bahasa Arab menarik minat jutaan penduduk dunia untuk mempelajarinya, karena sebagian istilah Islam berasal dari bahasa Arab juga telah diajarkan di pesantren-pesantren Indonesia. Banyak universitas internasional dan beberapa sekolah menengah internasional telah mengajarkan Bahasa Arab (Arabic as Foreign Language).Bahasa Arab berkembang semakin luas dengan munculnya software, siaran TV berbahasa Arab, dan pembelajaran online.

Membahas tentang "fungsi pembelajaran bahasa Arab" maka kita terlebih dahulu melihat pengertian "fungsi" itu sendiri lalu dikaitkan dengan beberapa permasalahan yang terkait dengannya yaitu bahasa, pembelajaran, dan bahasa Arab.

Berdasarkan gambaran makna fungsi secara mandiri tergambar dalam bagan berikut:

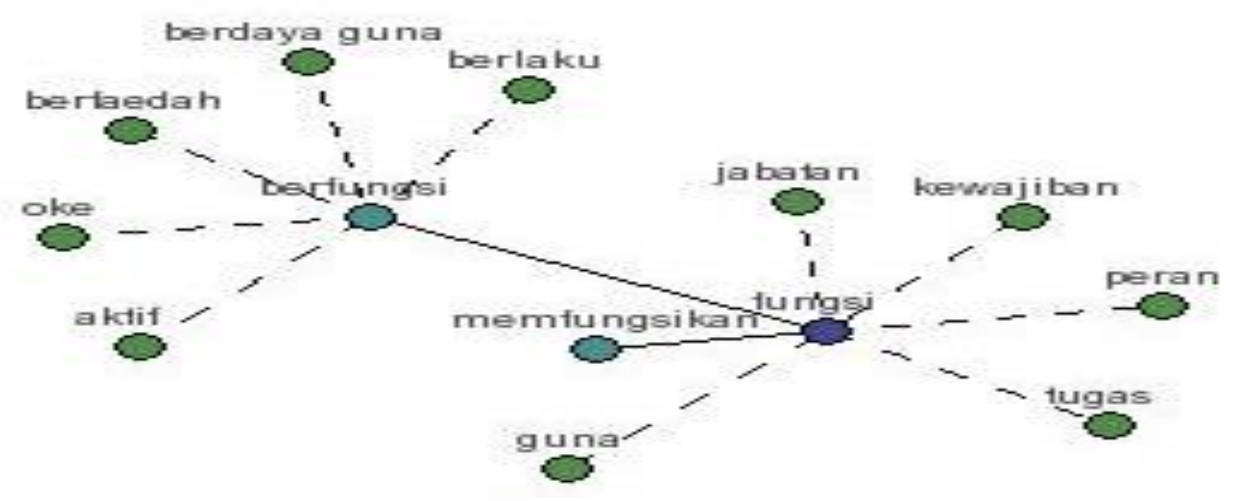

Fungsi yang berkaitan dengan bahasa ada beberapa hal yaitu:

Fungsi (noun) adalah peran sebuah unsur bahasa dalam satuan sintaksis yang lebih luas (seperti nomina berfungsi sbg subjek); -- ekspresif Ling penggunaan bahasa untuk menampakkan hal ihwal yang bersangkutan dengan pribadi pembicara; --fatis Ling penggunaan bahasa untuk mengadakan atau memelihara kontak antara pembicara dan pendengar; -- kognitif Ling 
penggunaan bahasa untuk penalaran akal; -- komunikatif Ling penggunaan bahasa untuk penyampaian informasi antara pembicara (penulis) dan pendengar (pembaca). ${ }^{3}$

Pembelajaran dapat diartikan proses, cara, perbuatan menjadikan orang atau makhluk hidup belajar. ${ }^{4}$

Bahasa Arab adalah salah satu bahasa yang memiliki fungsi-fungsi yang tersebut di atas. Oleh karena itu fungsi pembelajaran bahasa Arab dapat dimaknakan adalah suatu proses memfungsikan bahasa Arab kepada peserta didik atau pembelajar bahasa Arab baik dalam lingkup kebahasaan, kependidikan, sosial, keagamaan, dan kenegaraan.

Dr. H. Bisri Mustofa, M.A. dan H.M. Abdul Hamid, M.A. mengungkapkan dalam bukunya "Metode \& Strategi Pembelajaran Bahasa Arab" bahwa tujuan pembelajaran bahasa Arab jika dilihat pada sisi pendidik adalah agar dapat menjadikan bahasa Arab mudah dikuasai oleh para pelajar. Sementara bagi pelajar tujuannya adalah agar dapat menguasai bahasa Arab. Pada kesempatan lain mereka mengatakan bahwa pada umumnya motivasi dan dorongan mempelajari bahasa Arab di Indonesia adalah untuk tujuan agama, yaitu untuk mengkaji dan memperdalam ajaran Islam dan sumber-sumber yang berbahasa Arab. ${ }^{5}$

\section{Permasalahan Belajar Bahasa Arab}

Metode pembelajaran bahasa nampaknya sangat dipengaruhi oleh pendekatan atau al madhol apa yang mendasari seseorang terhadap persepsinya tentang bahasa. Banyak sekali asumsi tentang bahasa misalnyabahasa adalah kebiasaan (al-'adab) dan kebiasaan membutuhkan pengulangan dan pembiasaan. Asumsi lain mengatakan bahwa bahasa adalah habit (al-malakah) sedang tulisan hanyalah symbol. Yang lain mengatakan bahasa adalah apa yang diucapkan dan bukan apa yang seharusnya diucapkan. Masih banyak lagi asumsi-asumsi lain menyangkut bahasa yang dari asumsi itu melahirkan cara baik cara belajar maupun cara mengajar. Dari sini para pakar mengatakan bahwa pendekatan adalah sejumlah asumsi tentang bahasa. Dengan ungkapan yang sederhana dapat dikatakan bahwa bila asumsi orang tentang bahasa adalah lisan maka ia akan mengajarkan bagaimana keterampilan berbahasa harus dicapai dan materi apa yang sesuai untuk mencapai tujuan itu. Sebaliknya bila asumsi orang tentang

${ }^{3}$ http://www.artikata.com/arti-327473-fungsi.html

4http:/ / www.artikata.com/arti-357349-pembelajaran.html

${ }^{5}$ Dr. H. BisriMustofa, M.A. Dan H.M. Abdul Hamid, M.A., Metode E Strategi Pembelajaran Bahasa Arab, UIN Press, Malang, 2012, h.5-6 
bahasa adalah yang tertulis atau tulisan, maka yang akan diajarkan adalah bagaimana memahami yang ditulis. ${ }^{6}$

Berbagai problem tersebut antara lain ${ }^{7}$ :1) Mengapa belajar bahasa Arab membutuhkan waktu yang relatif lebih lama. Bukti konkritnya: siswa belajar bahasa Arab di SD selama 3 tahun (mulai kelas 4 sampai kelas 6); kemudian dilanjutkan ditingkat MTs selama 3 tahun; dilanjutkan di tingkan MA selama 3 tahun dan di dalam perguruan tinggi selama 4 tahun. sehingga kurun waktu untuk belajar bahasa Arab kurang lebih 13 tahun, tetapi hasil survei menyatakan masih banyak siswa yang belum mahir berbicara dalam bahasa Arab, sulit memahami teks-teks Arab dan kesulitan untuk menulis dalam tarkib Arab. Mengapa ini terjadi? Pasti di dalamnya terdapat berbagai kendala penghambatnya; 2) Mengapa motivasi siswa sangat rendah dalam belajar bahasa Arab? Mengapa? Apakah bahasa Arab adalah bahasa yang rumit dan sulit dicerna? atau metodenya monoton, atau kurang inovasi dari guru dalam mengemas pelajaran bahasa Arab menjadi menarik dan menyenangkan; 3) Bukubuku paket bahasa Arab terkesan sulit dan padat dengan materi. Serta isi buku terkadang tidak relevan dengan realitas siswa yang ada, sehingga hal ini menyebabkan siswa belajar bahasa arab kurang termotifasi; 4) Media bahasa Arab sangat terbatas. karena itu, dibutuhkan guru yang kreatif untuk menemukan dan membuat media pembelajaran bahasa Arab yang menarik. Sebab, peranan media sangat penting dalam mentransfer pengetahuan bahasa kepada siswa. Di toko-toko tidak dijual media-media bahasa Arab yang membahas tentang materi hiwar dalam kondisi tertentu. Kalaupun ada, itu pun untuk kalangan terbatas, film-film dan kartu-kartu bahasa Arab, poster-poster Arab, buku-buku cerita dalam bahasa Arab. Jika dibandingkan dengan bahasa Inggris, kita akan banyak menjumpai media pembelajaran bahasa Inggris di setiap toko-toko besar. Kapan media-media bahasa Arab tersedia di setiap toko?; 5). Di sebagian sekolah, tenaga pengajarnya bukan dari jurusan bahasa Arab (tidak memiliki keterampilan bahasa Arab yang memadai). ada guru yang mahir keterampilan bahasanya, tetapi keterampilan mengelola kelasnya kurang (bukan guru profesional) dan kalau ada guru yang profesionalnya tinggi, tetapi tidak diimbangi dengan kompetensi kemahiran berbahasa yang baik. Ini juga akan menentukan hasil pembelajaran bahasa Arab. Alangkah baiknya, jika terhadap guru yang memiliki keterampilan bahasa (istima', kalam, qiraah, dan kitabab) dan dia juga memiliki kompetensi dalam memanajemen kelas dengan piawai memilih metode, teknik, media, materi, dan mengetahui kondisi, motivasi, dan

6http:/ / arabbahasa.blogspot.com/2011/03/metode-dan-teknikpembelajaran-bahasa.html arab/

7http:/ / annajib.wordpress.com/2012/10/03/problem-pembelajaran-bahasa- 
kemampuan siswa-siswanya, sehingga dia dapat benar-benar dapat menyajikan pembelajaran bahasa Arab yang menyenangkan dan siswa dapat meningkatkan kompetensi bahasanya; 6) Waktu dan jam pembelajaran di sekolah hanya 2 jam pelajaran dalam satu minggu. Waktu yang terbatas membuat pembelajaran bahasa Arab semakin lama tercapai. Karena itu perlu ada jam tambahan (ekstra) untuk menambah jam belajar bahasa Arab; 7) Kurangnya faktor pendukung bagi perolehan bahasa Arab bagi siswa. Siswa jarang mendengarkan ungkapanungkapan arab, berbicara arab, membaca teks arab, dan menulis kalimat-kalimat arabiyah. Intinya faktor pendukung pembelajaran bahasa Arab adalah adanya lingkungan bahasa Arab. Jika ada lingkungan bahasa Arab, maka bahasa Arab dengan sendirinya terserap oleh siswa-siswa untuk kemudian diterapkan dalam komunikasi sehari-hari.

\section{Teknologi Pembelajaran}

Kata teknologi sering menggambarkan penemuan dan alat yang menggunakan prinsip dan proses penemuan saintifik yang baru ditemukan. Meskipun demikian, penemuan yang sangat lama seperti roda juga disebut sebuah teknologi.

Definisi lainnya (digunakan dalam ekonomi) adalah teknologi dilihat dari status pengetahuan kita yang sekarang dalam bagaimana menggabungkan sumber daya untuk memproduksi produk yang diinginkan (dan pengetahuan kita tentang apa yang bisa diproduksi). Oleh karena itu, kita dapat melihat perubahan teknologi pada saat pengetahuan teknik kita meningkat.

Dari Wikipedia bahasa Indonesia, ensiklopedi bebas menjelaskan tentang teknologi sebagai berikut: ${ }^{8}$ Teknologi adalah keseluruhan sarana untuk menyediakan barang-barang yang diperlukan bagi kelangsungan dan kenyamanan hidup manusia.Pada pertengahan abad ke-20, manusia telah mencapai kecukupan teknologi untuk kali pertama meninggalkan atmosfer Bumi dan menjelajahi ruang angkasa.Penggunaan teknologi oleh manusia diawali dengan pengubahan sumber daya alam menjadi alat-alat sederhana. Penemuan prasejarah tentang kemampuan mengendalikan api telah menaikkan ketersediaan sumber-sumber pangan, sedangkan penciptaan roda telah membantu manusia dalam beperjalanan dan mengendalikan lingkungan mereka. Perkembangan teknologi terbaru, termasuk di antaranya mesin cetak, telepon, dan Internet, telah memperkecil hambatan fisik terhadap komunikasi dan memungkinkan manusia untuk berinteraksi secara bebas dalam skala global. Tetapi, tidak semua teknologi digunakan untuk tujuan damai; pengembangan senjata penghancur

8http://id.wikipedia.org/wiki/Teknologi 
yang semakin hebat telah berlangsung sepanjang sejarah, dari pentungan sampai senjata nuklir.

Teknologi telah memengaruhi masyarakat dan sekelilingnya dalam banyak cara. Di banyak kelompok masyarakat, teknologi telah membantu memperbaiki ekonomi (termasuk ekonomi global masa kini) dan telah memungkinkan bertambahnya kaum senggang. Banyak proses teknologi menghasilkan produk sampingan yang tidak dikehendaki, yang disebut pencemar, dan menguras sumber daya alam, merugikan dan merusak Bumi dan lingkungannya. Berbagai macam penerapan teknologi telah memengaruhi nilai suatu masyarakat dan teknologi baru seringkali mencuatkan pertanyaanpertanyaan etika baru. Sebagai contoh, meluasnya gagasan tentang efisiensi dalam konteks produktivitas manusia, suatu istilah yang pada awalnyanya hanya menyangkut permesinan, contoh lainnya adalah tantangan norma-norma tradisionalbahwa keadaan ini membahayakan lingkungan dan mengucilkan manusia; penyokong paham-paham seperti transhumanisme dan teknoprogresivisme memandang proses teknologi yang berkelanjutan sebagai hal yang menguntungkan bagi masyarakat dan kondisi manusia. Tentu saja, paling sedikit hingga saat ini, diyakini bahwa pengembangan teknologi hanya terbatas bagi umat manusia, tetapi kajian-kajian ilmiah terbaru mengisyaratkan bahwa primata lainnya dan komunitas lumba-lumba tertentu telah mengembangkan alat-alat sederhana dan belajar untuk mewariskan pengetahuan mereka kepada keturunan mereka.

Teknologi pendidikan adalah kajian dan praktik untuk membantu proses belajar dan meningkatkan kinerja dengan membuat, menggunakan, dan mengelola proses dan sumber teknologi yang memadai. Istilah teknologi pendidikan sering dihubungkan dengan teori belajar dan pembelajaran. Bila teori belajar dan pembelajaran mencakup proses dan sistem dalam belajar dan pembelajaran, teknologi pendidikan mencakup sistem lain yang digunakan dalam proses mengembangkan kemampuan manusia.

Definisi "teknologi pendidikan" yang dijumpai dalam situs (http://id.wikipedia.org/wiki/Teknologi_pendidikan) menjelaskan definisinya sebagai berikut; 1) Systematic way of designing, implementing, and evaluating the total process of learning and teaching in terms of specific objectives, based on research in buman learning and communication and employing a combination of buman and non buman resources to bring about more effective instruction (Commission on Instructional Technology, 1970); 2) Educational technology is a field involved in the facilitation of buman learning through the systematic identification, development, organization and utilization of full range of learning

${ }^{9}$ Richey, R.C. (2008). Reflections on the 2008 AECT Definitions of the Field. TechTrends. 52 24-25 
resources and through the management of these process (AECT, 1972); 3) Instructional technology is the research in and application of behavioral science and learning theories and the use of a systems approach to analyze, design, develop, implement, evaluate and manage the use of technology to assist in the solving of learning or performance problems. The term instructional technology is often used interchangeably with the term educational technology, but instructional technology often has more emphasis on the scientific and systems approach of instructional problem solving while educational technology focuses more on the craft or art of using technology to support learning; 4) a Systematic way of designing, implementing and evaluating the total process of learning and teaching in terms of specific objectives, based on research in human learning and communication and employing a combination of human and non-buman resources to bring about more effective instruction" (U.S. Commission on Instructional Technology definition); 5) Educational technology is the study and ethical practice of facilitating learning and improving performance by creating, using, and managing appropriate technological processes and resources (AECT, 2004).

Berdasarkan definisi-definisi di atas menurut Ir. Lilik Gani HA, M.Sc.Ph.D dapat disimpulkan bahwa ${ }^{10}:$ 1) Teknologi pendidikan/teknologi pembelajaran adalah suatu disiplin/bidang (field of study); 2) Tujuan utama teknologi pembelajaran adalah (1) untuk memecahkan masalah belajar atau memfasilitasi pembelajaran; dan (2) untuk meningkatkan kinerja; 3) Teknologi pendidikan/pembelajaran menggunakan pendekatan system (pendekatan yang holistic/komprehensif, bukan pendekatan yang bersifat parsial); 4) Kawasan teknologi pendidikan dapat meliputi kegiatan analisis, desain, pengembangan, pemanfaatan,pengelolaan, implementasi dan evaluasi baik proses-proses maupun sumber-sumber belajar; 5) Yang dimaksud dengan teknologi dalam teknologi pendidikan adalah teknologi dalam arti luas, bukan hanya teknologi fisik (hardtech), tapi juga teknologi lunak (softtech); 6) Teknologi pendidikan adalah proses kompleks yang terintegrasi meliputi orang, prosedur, gagasan, sarana dan organisasi untuk menganalisis masalah dan merancang, melaksanakan, menilai dan mengelola pemecahan masalah dalam segala aspek belajar manusia.

Seperti yang dijelaskan di atas bahwa kawasan teknologi pendidikan dapat meliputi kegiatan analisis, desain, pengembangan, pemanfaatan, pengelolaan, implementasi dan evaluasi baik proses-proses maupun sumbersumber belajar. Tujuan teknologi dalam pembelajaran adalah untuk memanfaatkan teknologi dalam dunia pendidikan khusunya untuk teknologi informasi dan komunikasi. Dijelaskan oleh Jamal dalam bukunya "Tips Efektif Pemanfaatan Teknologi Informasi dan Komunikasi dalam Dunia Pndidikan" bahwa

${ }^{10 L i l i k}$ Gani, Peran Teknologi Pendidikan dalam Meningkatkan Akses, Mutu dan Relevansi Pendidikan di Indonesia, Bandung. Disampaikan pada Seminar Nasional dan Kolokium Teknologi Pendidikan di Bandung (04-05 Desember 2008) 
pembelajaran yang didukung oleh tekologi ini setidaknya akan berjalan efektif dengan: ${ }^{11}$ 1) Mengembangkan kemampuan peserta didik untuk memecahkan permasalahan - permasalahan dalam kehidupan nyata (kontekstual) sehingga pendidikan menjadi relevan dan responsive terhadap tuntutan kehidupan nyata sehari-hari. Implikasinya kurikulum menjadi lebih menarik dan dapat merangsang minat atau motivasi peserta didik karena dapat dengan mudah menerapkan pengetahuannya dalam kehidupan nyata sehari-hari; 2) Menumbuhkan pemikiran reflektif; serta 3) Membantu perkembangan dan keterlibatan aktif dari peserta didik dalam proses belajar.

\section{Penerapan Teknologi dalam Pembelajaran Bahasa Arab}

Dari beberapa permasalahan di atas dapat disimpulkan bahwa beberapa factor pembelajaran yang dilibatkan adalah: pengaturan materi untuk tiap jenjang (manajerial), motivasi peserta didik, pendekatan kontekstual, media pembelajaran, peningkatan kompetensi guru, efektivitas waktu pembelajaran, dan komunitas bahasa. Peran teknologi dapat mengambil fungsi-fungsi sebagai faktor-faktor pembelajaran.

\section{Internet}

Penggunaan internet dan web tidak hanya dapat memberikan kontribusi yang positip terhadap kegiatan akademik mahasiswa tapi juga bagi dosen.Internet dan web dapat memberi kemungkinan bagi dosen untuk menggali informasi dan ilmu pengetahuan dalam mata kuliah yang menjadi bidang kemampuannya. Melalui penggunaan internet dan web, dosen akan selalu siap mengajarkan ilmu pengetahuan yang mutakhir kepada mahasiswa. Hal ini tentu saja menuntut kemampuan dosen itu sendiri untuk selalu giat mengakses website dalam bidang yang menjadi keahliannya. Hal ini sejalan dengan definisi Pannen (2003) mengenai media dan teknologi pembelajaran di perguruan tinggi dalam arti luas yang mencakup perangkat keras (bardware), perangkat lunak (software), dan sumberdaya manusia (buman ware) yang dapat digunakan untuk memperkaya pengalaman belajar mahasiswa.

Penggunaan Internet untuk keperluan pendidikan yang semakin meluas terutama di negara-negara maju, merupakan fakta yang menunjukkan bahwa dengan media ini memang dimungkinkan diselenggarakannya proses belajar mengajar yang lebih efektif. Hal itu terjadi karena dengan sifat dan karakteristik Internet yang cukup khas, sehingga diharapkan bisa digunakan sebagai media

11 Jamal Ma'mur Asmani, Tips Efektif Pemanfaatan Teknologi Informasi dan Komunikasi dalam Dunia Pndidikan, DIVA Press, Yogyakarta, 2011, h. 115 
pembelajaran sebagaimana media lain telah dipergunakan sebelumnya seperti radio, televisi, CD-ROM Interkatif dan lain-lain.

Melalui internet, pembelajar dapat mengadakan kontak langsung dengan penutur asli, berpartisipasi dalam suatu forum diskusi, dan sebagainya. Interaksi antara dosen dan mahasiswa, misalnya penugasan dan pengerjaan tugas pun dapat dilakukan melalui internet. Disamping itu juga pemanfaatan program power-point digunakan untuk mengembangkan keterampilan wicara siswa/mahasiswa. Dalam hal ini, siswa/mahasiswa diberi tugas untuk menguraikan topik tertentu yang diminati selama beberapa menit dengan dukungan power-point.

Situs-situs yang berhubungan dengan bahasa Arab dan pendidikan Islam banyak disajikan di internet, baik yang menyajikan tentang tauhid, tasawuf, sejarah Islam, akidah-akhlak, dan bidang-bidang lainnya.Juga di internet sangat membantu penguasaan kemahiran berbahasa Arab. Karena situs-situs tersebut menyajikan berbagai data dan informasi masa lalu, terkini dan akan datang mengenai dunia Arab, dunia antar bangsa dan berbagai bidang-bidang kajian bahasa Arab dan Islam.

Situs-situs untuk bidang keislaman antara lain wmw.pesantren-online.com, atau www.google.com dengan mengetik apa yang diinginkan. Sedangkan situs-situs utama Arab adalah seperti wmw.arabic.com, wnw.raddadicom, www.arabia.com, wnw.alsaba.com, wnw.senbad.net dan lain sebagainya. Kalau dilihat dari situs www .raddadicom sebagai contoh, maka terlihat berbagai macam bidang yang ada dalam situs tersebut. Antara lain bidang-bidang yang diberikan adalah sebagai berikut: situs kesehatan, situs Islam, situs media massa, situs pekerjaan, situs sastra, situs komputer dan lain sebagainya.

\section{Interaktif}

Satu lagi perkembangan yang begitu pesat dan semakin modern makin mempermudah bagi seorang pendidik untuk memanfaatkan berbagai macam media yang ada, diantaranya adalah CD (compact disk) interaktif.

VCD juga merupakan media pengajaran bahasa yang cukup efektif digunakan. Alat ini mirip dengan tip recorder hanya lebih lengkap. Tip recorder hanya didengar, sementara VCD didengar dan dilihat. Saat ini telah banyak program-program pengajaran bahasa Arab yang dikemas dalam bentuk CD, namun untuk mengoperasikannya tidak cukup dengan VCD tetapi dengan komputer yang dilengkapi dengan multimedia. Dalam konteks pengajaran ALA, telah banyak program pengajaran ALA yang dikemas dalam bentuk CD, misalnya: Alif-Ba-Ta, Al-Qamus al-mushowwar li As-Shigar, BustanAr-Raudloh, Juha 1-2, Jism al-Insan, Hadiqah al-Arqam, Masrabiyah al-Huruf al-Arabiyah, Ta'lim al- 
Lughah al-Arabiyah, 'Alam al-Tajarub li as-Sigar, Jazirah al-Barka:n, dan Mausuah alMusabaqahwaal-Algha:z serta masih banyak lagi.

\section{Satelit/Parabola}

Satelit juga memberi kemudahan bagi para pendidik dalam mengajarkan bahasa Arab yakni dalam pengayaan kosa kata dan pengenalan budaya. Dengan piringan parabola, motor penggerak dan Digital Satellite Receiver, kita dapat menikmati siaran TV Arab, yaitu Saudi Arabia, Mesir, Yaman, Palestina, Abi Dhabi secara langsung. Satelit ini lebih banyak dimanfaatkan untuk keterampilan menyimak (mabaratul istima).

\section{Arabic E-learning}

Istilah e-learning mengandung pengertian yang sangat luas, sehingga banyak pakar yang menguraikan tentang definisi e-learning dari berbagai sudut pandang. Salah satu definisi yang cukup dapat diterima banyak pihak misalnya dari Darin E. Hartley [Hartley, 2001] yang menyatakan: e-learning merupakan suatu jenis belajar mengajar yang memungkinkan tersampaikannya bahan ajar ke siswa dengan menggunakan media Internet, Intranet atau media jaringan komputer lain. LearnFrame.Com dalam Glossary of e-Learning Terms [Glossary, 2001] menyatakan suatu definisi yang lebih luas bahwa: e-learning adalah sistem pendidikan yang menggunakan aplikasi elektronik untuk mendukung belajar mengajar dengan media internet, jaringan komputer, maupun komputer standalone.

Matthew Comer hero dalam E-Learning Concepts and Techniques [Bloomsburg, 2006] mendefinisikan: E-learning adalah sarana pendidikan yang mencakup motivasi diri sendiri, komunikasi, efisiensi, dan teknologi. Karena ada keterbatasan dalam interaksi sosial, siswa harus menjaga diri mereka tetap termotivasi.E-learning efisien karena mengeliminasi jarak dan arus pulang-pergi. Jarak dieliminasi karena isi dari e-learning didesain dengan media yang dapat diakses dari terminal komputer yang memiliki peralatan yang sesuai dan sarana teknologi lainnya yang dapat mengakses jaringan atau Internet.

$$
\begin{aligned}
& \text { "منظومة تعليمية لتقديم البرامج التعليمية او التدريبية للمتعلمين او المتدربين في أي } \\
& \text { وقت وفي أي مكان باستخدام تقنيات المعلومات والاتصالات التفاعلية مثل: } \\
& \text { الإنترنت، الإذاعة، القنوات المحلية او الفضائية للتلفاز، الأقراص الممغنطة، التلفزيون، } \\
& \text { البريد الإلكتروني، أجهزة الحاسوب، المؤتمرات عن بعد..) لتوفير بيئة تعليمية/تعلمية }
\end{aligned}
$$




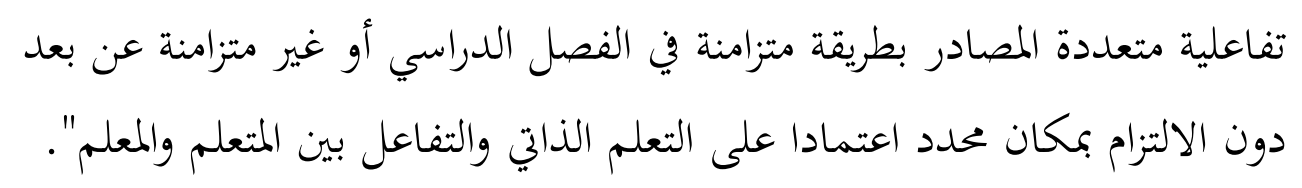

Dari definisi-definisi yang muncul dapat kita simpulkan bahwa sistem atau konsep pendidikan yang memanfaatkan teknologi informasi dalam proses belajar mengajar dapat disebut sebagai suatu e-learning. Sekarang ini, keberadaan e-learning semakin banyak bak jamur di musim hujan, terutama di situs perguruan tinggi. Seperti UI, UGM, UM, UPI, UNHAS, dan masih banyak lagi.

\section{Penutup}

Berbagai bentuk teknologi yang dapat digunakan dalam pembelajaran bahasa Arab adalah Internet dan web, CD Interaktif, Satelit/Parabola, Arabic Elearning,

Internet dan web dapat memberi kemungkinan bagi dosen untuk menggali informasi dan ilmu pengetahuan dalam mata kuliah yang menjadi bidang kemampuannya; media ini memang dimungkinkan diselenggarakannya proses belajar mengajar yang lebih efektif; melalui internet, pembelajar dapat mengadakan kontak langsung dengan penutur asli, berpartisipasi dalam suatu forum diskusi, dan sebagainya; interaksi antara dosen dan mahasiswa, misalnya penugasan dan pengerjaan tugas pun dapat dilakukan melalui internet; situs-situs yang berhubungan dengan bahasa Arab dan pendidikan Islam banyak disajikan di internet.

CD Interaktif yang terkait dengan program pengajaran bahasa Arab dikemas dalam bentuk CD, misalnya: Alif-Ba-Ta, Al-Qamus al-mushowwar li AsShigar, Bustan Ar-Raudloh, Juba 1-2, Jism al-Insan, Hadiqah al-Arqam, Masrahiyah alHuruf al-Arabiyah, Ta'lim al-Lughah al-Arabiyah, 'Alam al-Tajarub li as-Sigar, Jazirah al-Barka:n, dan Mausuah al-Musabaqah wa al-AlghaI.

Satelit/Parabola memungkinkan kita dapat menikmati siaran TV Arab, yaitu Saudi Arabia, Mesir, Yaman, Palestina, Abi Dhabi secara langsung.

Arabic E-learning memungkinkan tersampaikannya bahan ajar ke siswa dengan menggunakan media Internet, Intranet atau media jaringan komputer lain.

Kesimpulan dari pembahasan tentang penerapan teknologi dalam pembelajan bahasa Arab yaitu teknologi dapat berperan dalam keselarasan dan keberlanjutan pembelajaran bahasa Arab dari tingkat dasar hingga tingkat menengah atas, teknologi dapat membuat peserta didik akan semakin tertarik mempelajari bahasa Arab, teknologi dapat menciptakan realisasi dan relevansi 
dengan apa yang dirasakan peserta didik, teknologi dapat menciptakan mediamedia pembelajaran bahasa Arab yang lebih bervariasi yang selama ini masih terasa kurang, teknologi dapat meningkatkan kemampuan atau kompetensi guru dalam mengajar bahasa Arab, teknologi mampu memanfaatkan alokasi waktu untuk pembelajaran bahasa Arab, teknologi mampu menciptakan lingkungan berbahasa Arab.

\section{Daftar Kepustakaan}

Ahsanuddin, Mohammad, Pemanfaatan CD Interaktif Untuk Pembelajaran Bahasa Arab Untuk Anak (ALA).Makalah, 2004

, Pemanfaatan Internet Dalam Pembelajaran Bahasa Arab. Dalam: Al-Arabi, III (I): 1-13. 2005

Mustofa, Bisri, dan Hamid, H.M. Abdul, Metode dan Strategi Pembelajaran Bahasa Arab, UIN Press, Malang, 2012

Asmani, Jamal Ma'mur, Tips Efektif Pemanfaatan Teknologi Informasi dan Komunikasi dalam Dunia Pndidikan, DIVA Press, Yogyakarta, 2011

Kholidah, Lilik Nur, Dampak Globalisasi Terhadap Tugas Dan Tanggungjawab Kependidikan, Makalah, 2001

Gani, Lilik, Peran Teknologi Pendidikan dalam Meningkatkan Akses, Mutu dan Relevansi Pendidikan di Indonesia, Bandung. Disampaikan pada Seminar Nasional dan Kolokium Teknologi Pendidikan di Bandung (04-05 Desember 2008

Richey, R.C, Reflections on the 2008 AECT Definitions of the Field. TechTrends, 2008

Sudirman, Siahaan, Tips bagi Guru dalam Memanfaatkan Media Teknologi Informasi dan Komunikasi (TIK) untuk Pembelajaran. (on-line), (www.e-dukasi.net) 2008

Kees, Versteegh, The Arabic Language, hlm. 33. Edinburgh University Press, 1997 